\title{
What rates of productivity growth would be required to offset the effects of population aging? A study of twenty industrialized countries
}

\author{
Frank T. Denton \\ Byron G. Spencer ${ }^{1}$
}

\begin{abstract}
A shift in population distribution toward older ages is underway in industrialized countries throughout the world, and will continue well into the future. We provide a framework for isolating the pure effects of population aging on per-capita GDP, employ the framework in calculations for twenty OECD countries, and derive the rates of productivity growth required to offset those effects. Taking the twenty countries as a whole, the average productivity growth rate (a simple unweighted arithmetic average) required just to offset aging effects over the full thirty years from 2015 to 2045 would be 4.2 per cent per decade, or approximately 0.4 per cent per year; to achieve an overall increase of 1 per cent in GDP per capita would require an average rate of 15.1 per cent per decade, or 1.4 per cent per year. We also consider some labour-related changes that might provide offsets, for comparison with productivity.
\end{abstract}

Keywords: population aging; productivity; industrialized countries; projections.

\section{Résumé}

Les pays industrialisés du monde entier vivent actuellement une modification de la distribution de leur population vers le vieillissement, et cette tendance se maintiendra à l'avenir. Nous donnons un cadre permettant d'en isoler les effets purement liés au vieillissement de la population par tête du PIB; nous utilisons ce cadre pour calculer les effets dans vingt pays de l'OCDE et en tirons les taux de croissance de productivité nécessaires pour compenser les effets de ce vieillissement. Si on considère les vingt pays comme un ensemble, le taux moyen de croissance de la productivité (simple moyenne mathématique non pondérée) nécessaire pour compenser l'effet du vieillissement de la population sur trente années complètes de 2015 à 2045 serait de 4,2 pour cent sur 10 ans, ou environ 0,4 pour cent par année. Pour arriver à une augmentation générale de 1 pour cent du PIB par tête il faudrait un taux moyen de 15,1 pour cent sur dix ans, ou 1,4 pour cent par année. Nous tenons aussi compte de quelques changements relatifs au travail pour comparer la productivité.

Mots-clés : vieillissement de la population; productivité; pays industrialisés; projections.

\section{Introduction}

The demographic shift toward older ages is underway in industrialized countries throughout the world and will continue well into the future. If unmitigated, the economic effects will be widespread and diverse. At a basic level they will be principally the result of a decline in the availability of labour supply in relation to an aging and increasingly dependent population, with a consequent reduction of real gross domestic product per capita. However, there is the possibility that growth

1. Byron G. Spencer, corresponding author: Professor Emeritus of Economics, McMaster University,

Hamilton, ON L8S 4M4, email: spencer@mcmaster.ca; and Frank T. Denton, Department of Economics, McMaster University. 
in aggregate productivity could provide an offset, and we consider what rates of growth would be required to avoid declines in incomes and, more ambitiously, to have them grow. Given a set of forecasts of the population, we develop a framework for isolating pure demographic effects on per capita gross domestic product (GDP) and calculating the required offsetting productivity growth rates. We show also how other possible offsets can be calculated within the same framework, and compare them with the productivity offset. Calculations within that framework are carried out for the top twenty OECD countries ranked in 2015 by GDP per capita (OECD 2017c; two small countries, Luxembourg and Iceland, are omitted from the ranking).

Concern about the slowing rate of population growth and its consequences is not new; it dates back more than eight decades. John Maynard Keynes, for one, confidently stated that population decline was in prospect:

We know much more securely than we know almost any other social or economic factor relating to the future that, in the place of the steady and indeed steeply rising level of population which we have experienced for a great number of decades, we shall be faced in a very short time with a stationary or a declining level (1937: 13).

He expressed grave concern about its economic consequences: "The [...] result to prosperity of a change-over from an increasing to a declining population may be very disastrous" (Keynes 1937: 14).

Such concern was echoed by Alvin Hansen, who stated in his presidential address to the American Economic Association that since "we are in the midst of a drastic decline in the rate of population growth $[. .$.$] it behooves us as economists to take cognizance of the significance of this$ revolutionary change in our economic life" (1939:2) and then proceeded to introduce the concept of secular stagnation (1939: 4).

Concerns with the declining rate of population growth and its economic implications dissipated abruptly with the rapid rise in fertility that started only a few years later. However, they began to reappear in the 1970s and 1980s, as the longer-run relationships between population change and economic performance began to receive more careful attention (see, for example, Denton and Spencer 1973; IUSSP 1979; Lee et al. 1988; and Steinmann 1984). It was becoming clear that the transition from the high fertility rates that followed World War II to persistently much lower rates in the 1960s and thereafter implied a fundamental and probably long-lasting shift in population age distribution in many industrialized countries. Demographers and others realized that the temporary postwar fertility "boom" would give rise first to an echo effect, as the postwar children reached adulthood and had their own children (with much lower fertility), but then a pronounced aging effect as they moved on and into retirement and dependency in large numbers in the early decades of the 21 st century, an effect strengthened by concurrent increases in life expectancy. Evidence of economic problems to come became more apparent as time passed, and there was increasing concern about how to deal with rising health care, pension, and other costs associated with an older population in the face of a reduction in the labour force/dependency ratio, and hence in the level of output per capita that an economy could sustain. ${ }^{2}$

Concern about the economic effects of population continues today, although without consensus about severity. Bloom and colleagues argue that "OECD countries are likely to see modest [...] declines in the rate of economic growth," but go on to suggest that "behavioral responses [...] and policy reforms [...] can mitigate the economic consequences of an older population" (2011: 2). A report of the National Research Council, co-chaired by Ronald Lee, agrees: "the impact of an ag-

2. Dependency ratios are time-honoured (if crude) measures of the ability of a population to support itself; Denton and Spencer (2000) provide a review and critique of the concept. 
ing population on overall living standards is likely to be modest" in the United States (2012: 3-4). Maestas and colleagues are less optimistic; they conclude, using US state-level data, that a "10\% growth in the fraction of the population ages 60 and older decreases growth in GDP per capita by $5.5 \%$ " and that "two-thirds of the reduction is driven by a reduction in the rate of growth of [...] labor productivity" (2016: 4).

There is also a renewed concern about secular stagnation. The papers in Teulings and Baldwin (2014) summarize much of the debate; Summers (2014) focuses on the demand side and on the limitation of monetary policy in attaining full employment, while Gordon (2014) anticipates that the growth of productive potential itself will be reduced by four "headwind" barriers, one of which is demographic (the other three are education, inequality, and government debt; see also Gordon 2016; Summers 2016). On the other hand, based on cross-country comparisons Acemoglu and Restrepo find "no negative relationship between population aging and slower growth of GDP per capita" and conclude that "one possible explanation [...] is the endogenous response of technology" (2017: 10).

The present paper is intended as a contribution to this somewhat diverse literature by providing and employing a well-defined framework for quantifying the prospective supply-side effects of population aging on future GDP per capita over the period 2015-45 in twenty industrialized countries, and particularly the potential for offsetting those effects through productivity growth, were such growth to take place. Population aging may affect patterns of consumption as well-namely, the ways in which GDP is used as the age distribution changes-but that is not our concern here. Our focus is the supply side of the economy in relation to the size of the population.

\section{Background: The current outlook for population change}

We consider first the demographic outlook for our twenty selected countries, in particular the prospective changes in age structure of their populations over the thirty-year period 2015-45.

Table 1. Projected percentages of population in dependent age groups.

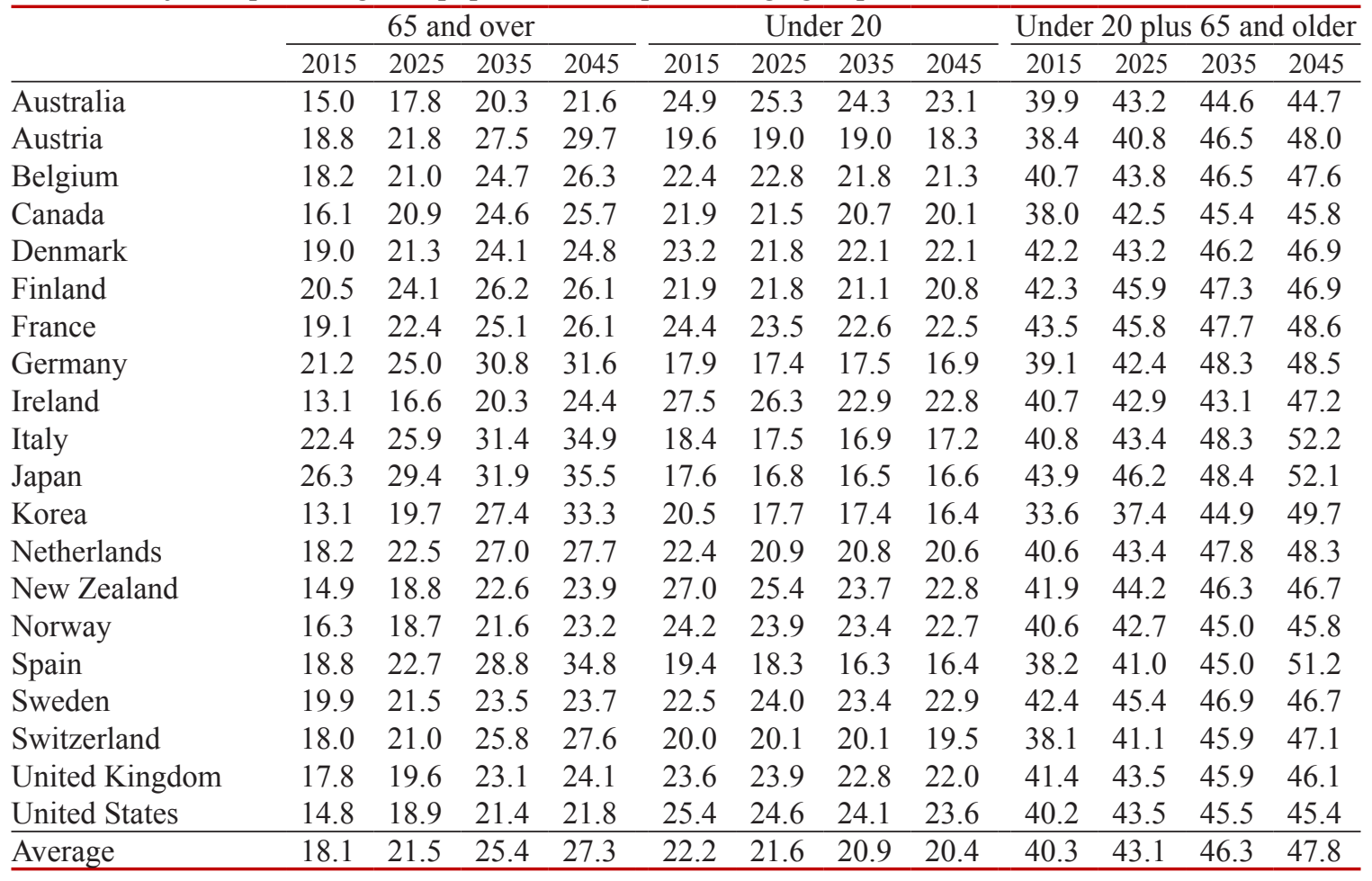


The term population aging usually brings to mind only the increase in the share of older population. But aging, in the sense of rising average age, could as well come from a decline in the proportion of the younger population. From the point of view of effects on GDP per capita, the more fundamental demographic issue is the change in the proportion of dependents in the population, whether young or old, and the associated change in the working-age and labour force proportions. Population aging means an increase in the share of older people, but it is of interest to consider initially both ends of the age spectrum. To that end, in Table 1 we show projected percentage shares of the population aged 65 and over, projected shares of the population under 20, and the two combined. We refer to these age groups as the dependent population; although some under 20 or over 65 years old are in fact in the labour force, while some in the 20-65 age range are not, these boundaries are used to approximate the changes in age structure of relevance here. ${ }^{3}$ The shares in Table 1 are calculated from population projections provided by the United Nations (2017). The UN offers a number of alternative projections based on different assumptions; we have chosen the ones labelled "medium."

Table 1 makes clear just how widespread the prospective shift in age structure is. Starting at the old end, the proportion 65 years of age and over increases in every one of the twenty countries between 2015 and 2025, and again between 2025 and 2035; nineteen of the countries show a further increase between 2035 and 2045. Taking the thirty-year period as a whole, the (unweighted) average proportion increases by 9.2 percentage points (18.1 to 27.3); the largest increase is 20.2 percentage points (Korea), the smallest is 3.8 (Sweden). There are some offsets at the other end of the age spectrum, with a few countries showing increases in the proportion aged under 20. However, most show declines and the average under- 20 proportion falls by 1.8 percentage points. Overall, the changes at the young end of the spectrum are dominated by changes at the old end. The dependent population share, as we call it-i.e., the two groups combined-increases generally in the same manner as the 65-and-over share: every country shows an increase in the first two decades and all but three in the third; over the whole of the 30-year span, every country shows an increase. The average dependent share increases from 40.3 per cent in 2015 to 47.8 per cent in 2045.

\section{A framework for analysis}

The initial variables of interest are symbolized as follows: $Y$ for (real) GDP, $N$ for population, $L$ for labour force, $E$ for employed labour force, $U$ for unemployed labour force, $H$ for total hours worked, and $\bar{H}$ for total efficient hours worked (definition to follow). Subscripts $t$ for time period and $x$ for age-sex group (hereafter ASG) are attached as needed; variables with no $x$ subscript are aggregates over the entire population or derived aggregate ratios. Productivity is symbolized as $p$ and defined as GDP/ $\bar{H}$.

The productivity variable merits special comment. Although conventionally labeled "labour productivity," it has of course a more general interpretation. Namely, it can be viewed as determined by several broadly defined influences: the quality of labour (education, training, experience); the capital/labour ratio (capital itself consisting of many types); the ratio of other inputs to labour input (land, raw or processed materials); the state of technology, in its many aspects; the rate of dissemination of new technology among firms and industries; possible returns to the scale of

3. In one of our experiments below, we consider the effects of possible increases in the labour force participation rates of the 65 -and-over population.

4. The main alternative projections assume that by 2030, country-specific fertility rates either become higher or lower by 0.5 or remain constant; each is combined with the assumptions about future mortality and migration. A different choice would likely have little effect on the overall conclusions of the analysis to follow. 
production; and the industrial distribution of aggregate labour (overall productivity can increase by a reallocation from lower to higher productivity industries). All of these possible determinants should be kept in mind when we talk about increases in $p$ below as a possible offset to the effects of population aging. One usually thinks of advances in technology as responsible for productivity growth but any or all of the other influences noted could be in play, alone or in conjunction with changing technology. ${ }^{5}$

Now consider the following identity:

$$
y=p \Sigma_{x} r_{x} e_{x} h_{x} q_{x} n_{x},
$$

where $y=Y / N ; r_{x}=L_{x} / N_{x} ; e_{x}=E_{x} / L_{x} ; h_{x}=H_{x} / E_{x} ; q_{x}=\bar{H}_{x} / H_{x}$; and $n_{x}=N_{x} / N$. In words, per capita GDP is equal to the product of the labour force participation rate, the fraction of the labour force employed, average hours worked, the work efficiency ratio (as we shall call it), and the population share, summed over all ASGs and multiplied by the productivity ratio. (Note for later use that $e_{x}=1-u_{x}$, where $u_{x}=U_{x} / L_{x}$ is the unemployment rate for ASG $x$.)

Our concern is the disadvantageous effect of prospective demographic change on GDP per capita. As discussed above, the most important and widely recognized effect is the increase in the proportion of older dependents as a population ages and the consequent reduction of the proportion in the labour force. But there is another possible effect of interest-the shift in age distribution within the labour force itself. A question that one could ask is whether an hour worked by a new young labour force member should be treated as the equivalent of an hour worked by someone more experienced, or whether an hour worked by an older worker near retirement age should be considered as productive as one contributed by a middle-aged worker. Younger workers may lack experience, but their more recent education and training may give them an advantage in the application of newer knowledge and techniques. Older workers, more experienced as they are, may nevertheless lack that advantage. (Some of the relevant literature is discussed below.) We know of no data that would allow us to do definitive calculations to answer questions of this kind, but we can ask whether differences, if they do exist to any substantial degree, could matter. Could the effects of population aging on GDP per capita differ significantly if we were able to take differences in the age distribution of the labour force into account? We have allowed for the possibility that such differences might in fact matter by distinguishing between $H$ and $\bar{H}$ and incorporating ASG-specific work efficiency ratios in equation (1): an hour of $\bar{H}$ is of the same productive quality, whatever the age or sex of the worker, but that need not be true of $H$. Aggregate productivity can be written as $p=Y / \bar{H}=Y / \Sigma \bar{H}_{x}=Y / \Sigma q_{x} H_{x}$. In the initial calculations below, we simply accept the absence of data and set $q_{x}=1$ for all $x$. In some subsequent ones, though, we experiment with alternative assumptions about the $q_{x}$ values to see whether different assumptions might mitigate or augment the calculated effects of population aging.

\section{An index of pure demographic effects on GDP per capita}

We define pure demographic effects as the changes that occur to GDP per capita when only the age-sex distribution of the population is allowed to vary. With that in mind, we now attach time subscripts to the variables, choose $t=0$ as a base year (we will be working with annual data), adapt equation (1), and write

5. The determinants of labour productivity are most often implicit in production theory, but reformulation of a production equation can place output per unit of labour on the left side and make the relationships explicit. 


$$
y_{t}=p_{t} \Sigma_{x} a_{x t} n_{x t}
$$

where $a_{x t}=r_{x t} e_{x t} h_{x t} n_{x t}$. Then, setting $t=0$ and hence $a_{x t}=a_{x 0}$, we write

$$
\bar{y}_{t}=\bar{p}_{t}\left(\Sigma_{x} a_{x 0} n_{x t}\right) /\left(\Sigma_{x} a_{x 0} n_{x 0}\right)=\bar{p}_{t} \bar{d}_{t}
$$

where $\bar{p}_{t}=p_{t} / p_{0}$ is an index of overall productivity; $\bar{d}_{t}$ is an index of pure demographic effects, and $\bar{y}_{t}=y_{t} / y_{0}$ is an index of per capita GDP, conditional on $\bar{p}_{t}$ and $\bar{d}_{t}$. Now, replace $\bar{p}_{t}$ with $\bar{p}_{0}=1$ so that $\bar{y}_{t}=\bar{d}_{t}$. The value of $\bar{d}_{t}$ then answers the question, what would the index of per capita GDP be in year $t$ if the productivity level and all of the components of $a$ were to remain constant at their year 0 levels and only the values of $n$ were to change?

In the world of price indexing, $\bar{d}_{t}$ would be called a Laspeyres or base-weighted index: $x$ could stand for type of commodity, $n$ could be replaced by price, and $a$ could be replaced by quantity purchased. Holding quantities purchased constant for indexing purposes does not imply that there would be no behavioural response of quantities to price changes; it is simply for the purpose of isolating one type of change from the other. Similarly, holding the $a_{x}$ values constant while allowing the $n_{x}$ values to change does not imply that there would be no behavioural responses of participation rates, employment rates, or average hours to changes in population structure. The aim is simply to identify the pure or direct effects of population changes on GDP per capita.

\section{Productivity growth as a possible offset}

In practice, $\bar{d}_{t}$ calculated from predicted population numbers will generally be less than 1 for $t>0$, as we will show below, and may be regarded as representing future downward effects of population aging on GDP per capita. We can then ask, what level of productivity would be needed to offset the effects of aging? 'To put it more concretely, what value of $\bar{p}_{t}$ would be required to yield $\bar{y}_{t}=k_{t}$, where $k_{t}$ is the target level of GDP per capita for year $t$ ? Let us call the required level of the productivity index $\dot{p}_{t}$, which is calculated as $\dot{p}_{t}=k_{t} / \bar{d}_{t}$. If the goal is to maintain the level of GDP per capita that prevailed in the base year, then $k_{t}=1$; if some annual rate of increase $\pi$ in GDP per capita is the goal, then $k_{t}=(1+\pi)^{t}$.

\section{Other possible offsets}

Our principal focus is productivity growth as an offset to future population aging, but equation (3) suggests the possibility of alternatives: $r, e$, or $h$ could vary. To explore the effects of increased labour force participation rates, for example, we can redefine $a$ as $a^{\prime}$ and rewrite equation (2) as

$$
y_{t}=p_{0} \Sigma_{x} a_{x t}^{\prime} r_{x t} n_{x t}
$$

where $a_{x t}^{\prime}=e_{x t} h_{x t} q_{x t}$. We can then make corresponding changes to equation (3) and write

$$
\bar{y}_{t}=\bar{p}_{0}\left(\Sigma_{x} a_{x 0}^{\prime} r_{x t} n_{x t}\right) /\left(\Sigma_{x} a_{x 0}^{\prime} r_{x 0} n_{x 0}\right)=\bar{p}_{0} \bar{g}_{t}=\bar{g}_{t} \text {. }
$$

Note that $\bar{g}_{t}$ is a combined index of demographic and participation rate effects and $\bar{p}_{0}$ is set to 1 , since participation rate changes now replace productivity change in the exploratory calculation. Changes in the employment ratio and hours worked can be handled in a similar fashion, redefining $\bar{g}_{t}$ accordingly. We investigate below how effective changes in all three of these variables might be as an alternative to productivity growth in offsetting the future effects of population aging.

The work efficiency ratios are not observable in any year, including the base year $t=0$, and they are thus just a matter of assumption from the beginning. However the effects of alternative 
assumptions about them can be investigated by resetting the $q_{x 0}$ components of $a_{x 0}$ in equation (3) and recalculating $\bar{d}_{t}$. Were we to make alternative assumptions about the $q_{x 0}$ values, would that increase or decrease the effects of prospective population aging and require a significantly different rate of productivity growth to provide an offset?

\section{Data and derived variables}

The set of population projections that we use for our twenty countries is the medium variant of the several sets published by the United Nations (2017), as noted above. (The methodology is described in United Nations 2015.) With one necessary and limited exception, observations for all other variables (required for the base year 2015) are calculated using OECD data (2017a, b, d), based on labour force survey information reported by member countries. The calculations of $r, e$, and $h$ are thus based on OECD data. ${ }^{6}$

Survey coverage and definitions do vary to some extent among member countries; the OECD compiles and publishes the data for individual countries in as consistent a form as it can, but complete uniformity is not possible. That implies some distortion in the inter-country comparisons in our calculations. The degree of distortion is expected to be small, though, in comparison with the demographic changes that drive the results reported below. Aside from survey and coverage differences, there are detailed reporting differences among countries that had to be dealt with, especially with regard to grouping at the older end of the age scale, but of other kinds as well. We have made adjustments where necessary to allow for these differences. (See Appendix for further discussion and details of the data and associated calculations.)

Table 2. Projected indexes of GDP per capita when only the population changes.

\begin{tabular}{|c|c|c|c|c|c|c|c|c|}
\hline & \multicolumn{4}{|c|}{ Index } & \multicolumn{4}{|c|}{ Percentage change } \\
\hline & 2015 & 2025 & 2035 & 2045 & $2015-25$ & $2025-35$ & $2035-45$ & $2015-45$ \\
\hline Australia & 100.0 & 95.8 & 93.9 & 93.3 & -4.2 & -2.0 & -0.7 & -6.7 \\
\hline Austria & 100.0 & 92.7 & 85.6 & 82.7 & -7.3 & -7.7 & -3.4 & -17.3 \\
\hline Belgium & 100.0 & 93.9 & 89.2 & 87.6 & -6.1 & -5.0 & -1.9 & -12.4 \\
\hline Canada & 100.0 & 94.2 & 90.2 & 88.9 & -5.8 & -4.2 & -1.5 & -11.1 \\
\hline Denmark & 100.0 & 98.0 & 93.7 & 92.6 & -2.0 & -4.4 & -1.2 & -7.4 \\
\hline Finland & 100.0 & 94.9 & 93.4 & 93.0 & -5.1 & -1.6 & -0.3 & -7.0 \\
\hline France & 100.0 & 95.2 & 92.6 & 92.3 & -4.8 & -2.7 & -0.3 & -7.7 \\
\hline Germany & 100.0 & 93.8 & 86.4 & 84.7 & -6.2 & -8.0 & -1.9 & -15.3 \\
\hline Ireland & 100.0 & 95.4 & 94.5 & 90.6 & -4.6 & -1.0 & -4.2 & -9.4 \\
\hline Italy & 100.0 & 93.6 & 85.6 & 80.8 & -6.4 & -8.5 & -5.6 & -19.2 \\
\hline Japan & 100.0 & 96.4 & 92.7 & 88.5 & -3.6 & -3.8 & -4.6 & -11.5 \\
\hline Korea & 100.0 & 99.3 & 92.0 & 86.3 & -0.7 & -7.3 & -6.2 & -13.7 \\
\hline Netherlands & 100.0 & 94.3 & 88.9 & 88.2 & -5.7 & -5.8 & -0.8 & -11.8 \\
\hline New Zealand & 100.0 & 97.6 & 95.2 & 95.1 & -2.4 & -2.5 & -0.1 & -4.9 \\
\hline Norway & 100.0 & 96.5 & 92.5 & 90.7 & -3.5 & -4.1 & -2.0 & -9.3 \\
\hline Spain & 100.0 & 92.6 & 85.1 & 77.9 & -7.4 & -8.0 & -8.6 & -22.1 \\
\hline Sweden & 100.0 & 95.9 & 92.9 & 92.8 & -4.1 & -3.1 & -0.1 & -7.2 \\
\hline Switzerland & 100.0 & 93.6 & 87.6 & 85.1 & -6.4 & -6.4 & -2.9 & -14.9 \\
\hline United Kingdom & 100.0 & 96.1 & 93.1 & 92.1 & -3.9 & -3.1 & -1.1 & -7.9 \\
\hline United States & 100.0 & 96.6 & 93.9 & 93.3 & -3.4 & -2.8 & -0.7 & -6.7 \\
\hline Average & 100.0 & 95.3 & 91.0 & 88.8 & -4.7 & -4.6 & -2.4 & -11.2 \\
\hline
\end{tabular}

6. Note that participation rates $(r)$ are calculated by us using UN total population numbers by age/sex group as denominators rather than survey population numbers, which may differ among countries because of differences in survey coverage. 


\section{Future GDP per capita when there is no offset to population aging}

We apply equation (3) now, with $\bar{p}_{t}=\bar{p}_{0}=1$, to calculate the $\bar{d}_{t}$ indexes, representing the pure effects of population aging on GDP per capita over three decades starting from 2015. The results are provided in Table 2. The first and most conspicuous result to be observed in Table 2 is the commonality of declines. All twenty countries show a drop in the GDP per capita index in each of the three decades. The average decline between 2015 and 2045 for all countries combined is 11.2 per cent. There is considerable diversity in the extent of the declines, but no doubt about their prevalence. The effect of population aging on GDP per capita among industrialized countries is clearly widespread, as is population aging itself.

Looking further at the table, we note that nine countries show a decline in GDP per capita of as much as 5 per cent or more in the first decade, and ten show a decline of 10 per cent or more over the thirty-year period as a whole, while one country, Spain, shows a decline of 22.1 per cent.

\section{Productivity growth rates that would be required to offset population aging}

As noted earlier, if we assume a target annual GDP per capita growth rate $\pi$, the level of productivity required by year $t$ consistent with that rate is $\dot{p}_{t}=(1+\pi)^{t} / \bar{d}_{t}$. We consider two possibilities in application: $\pi=0$ (the base year level of GDP per capita is maintained) and $\pi=.01$ (GDP per capita increases by one per cent per year). Table 3 shows results for $\dot{p}_{t}$ when $\pi=0$, in each of the three decades from 2015 to 2045, in terms of both index levels and rates of growth. Table 4 shows results when $\pi=.01$. The levels of $\dot{p}_{t}$ when $\pi=0$ and the corresponding levels of $\bar{d}_{t}$ are plotted in Figure 1 for the ten countries with the largest populations in 2015.

To maintain the 2015 level of GDP per capita would require positive increases in productivity in every one of the twenty countries over the whole of the period 2015-45, and in every component decade. (The decade rates shown in Table 3 are all positive; a few of the corresponding annual

Table 3. Percentage rates of growth of productivity required in each period to prevent GDP per capita from declining.

\begin{tabular}{|c|c|c|c|c|c|c|c|c|}
\hline & \multicolumn{4}{|c|}{ Growth rate per decade } & \multicolumn{4}{|c|}{ Growth rate per year } \\
\hline & $2015-25$ & $2025-35$ & $2035-45$ & $2015-45$ & $2015-25$ & $2025-35$ & $2035-45$ & $2015-45$ \\
\hline Australia & 4.4 & 2.0 & 0.7 & 2.4 & 0.4 & 0.2 & 0.1 & 0.2 \\
\hline Austria & 7.9 & 8.3 & 3.5 & 6.6 & 0.8 & 0.8 & 0.3 & 0.6 \\
\hline Belgium & 6.5 & 5.2 & 1.9 & 4.5 & 0.6 & 0.5 & 0.2 & 0.4 \\
\hline Canada & 6.2 & 4.4 & 1.5 & 4.0 & 0.6 & 0.4 & 0.1 & 0.4 \\
\hline Denmark & 2.0 & 4.6 & 1.2 & 2.6 & 0.2 & 0.5 & 0.1 & 0.3 \\
\hline Finland & 5.4 & 1.7 & 0.3 & 2.4 & 0.5 & 0.2 & 0.0 & 0.2 \\
\hline France & 5.1 & 2.8 & 0.3 & 2.7 & 0.5 & 0.3 & 0.0 & 0.3 \\
\hline Germany & 6.6 & 8.7 & 2.0 & 5.7 & 0.6 & 0.8 & 0.2 & 0.6 \\
\hline Ireland & 4.8 & 1.0 & 4.4 & 3.4 & 0.5 & 0.1 & 0.4 & 0.3 \\
\hline Italy & 6.8 & 9.3 & 6.0 & 7.4 & 0.7 & 0.9 & 0.6 & 0.7 \\
\hline Japan & 3.7 & 4.0 & 4.8 & 4.2 & 0.4 & 0.4 & 0.5 & 0.4 \\
\hline Korea & 0.8 & 7.9 & 6.6 & 5.0 & 0.1 & 0.8 & 0.6 & 0.5 \\
\hline Netherlands & 6.0 & 6.1 & 0.8 & 4.3 & 0.6 & 0.6 & 0.1 & 0.4 \\
\hline New Zealand & 2.5 & 2.5 & 0.1 & 1.7 & 0.2 & 0.3 & 0.0 & 0.2 \\
\hline Norway & 3.6 & 4.3 & 2.0 & 3.3 & 0.4 & 0.4 & 0.2 & 0.3 \\
\hline Spain & 8.0 & 8.8 & 9.4 & 8.7 & 0.8 & 0.8 & 0.9 & 0.8 \\
\hline Sweden & 4.3 & 3.2 & 0.1 & 2.5 & 0.4 & 0.3 & 0.0 & 0.2 \\
\hline Switzerland & 6.8 & 6.8 & 3.0 & 5.5 & 0.7 & 0.7 & 0.3 & 0.5 \\
\hline United Kingdom & 4.1 & 3.2 & 1.1 & 2.8 & 0.4 & 0.3 & 0.1 & 0.3 \\
\hline United States & 3.5 & 2.8 & 0.7 & 2.4 & 0.3 & 0.3 & 0.1 & 0.2 \\
\hline Average & 5.0 & 5.0 & 2.6 & 4.2 & 0.5 & 0.5 & 0.3 & 0.4 \\
\hline
\end{tabular}


Table 4. Percentage rates of growth of productivity required in each period to keep GDP per capita growing at $1 \%$ per year.

\begin{tabular}{|c|c|c|c|c|c|c|c|c|}
\hline & \multicolumn{4}{|c|}{ Growth rate per decade } & \multicolumn{4}{|c|}{ Growth rate per year } \\
\hline & $2015-25$ & $2025-35$ & $2035-45$ & $2015-45$ & $2015-25$ & $2025-35$ & $2035-45$ & $2015-45$ \\
\hline Australia & 15.3 & 12.7 & 11.2 & 13.1 & 1.4 & 1.2 & 1.1 & 1.2 \\
\hline Austria & 19.2 & 19.6 & 14.4 & 17.7 & 1.8 & 1.8 & 1.4 & 1.6 \\
\hline Belgium & 17.7 & 16.2 & 12.6 & 15.5 & 1.6 & 1.5 & 1.2 & 1.4 \\
\hline Canada & 17.3 & 15.3 & 12.1 & 14.9 & 1.6 & 1.4 & 1.2 & 1.4 \\
\hline Denmark & 12.7 & 15.6 & 11.8 & 13.3 & 1.2 & 1.5 & 1.1 & 1.3 \\
\hline Finland & 16.4 & 12.3 & 10.8 & 13.1 & 1.5 & 1.2 & 1.0 & 1.2 \\
\hline France & 16.0 & 13.5 & 10.8 & 13.4 & 1.5 & 1.3 & 1.0 & 1.3 \\
\hline Germany & 17.7 & 20.0 & 12.6 & 16.8 & 1.6 & 1.8 & 1.2 & 1.6 \\
\hline Ireland & 15.8 & 11.5 & 15.3 & 14.2 & 1.5 & 1.1 & 1.4 & 1.3 \\
\hline Italy & 18.0 & 20.8 & 17.1 & 18.6 & 1.7 & 1.9 & 1.6 & 1.7 \\
\hline Japan & 14.6 & 14.8 & 15.8 & 15.1 & 1.4 & 1.4 & 1.5 & 1.4 \\
\hline Korea & 11.3 & 19.2 & 17.8 & 16.0 & 1.1 & 1.8 & 1.6 & 1.5 \\
\hline Netherlands & 17.1 & 17.2 & 11.3 & 15.2 & 1.6 & 1.6 & 1.1 & 1.4 \\
\hline New Zealand & 13.2 & 13.3 & 10.6 & 12.3 & 1.2 & 1.3 & 1.0 & 1.2 \\
\hline Norway & 14.4 & 15.2 & 12.7 & 14.1 & 1.4 & 1.4 & 1.2 & 1.3 \\
\hline Spain & 19.3 & 20.1 & 20.8 & 20.1 & 1.8 & 1.9 & 1.9 & 1.8 \\
\hline Sweden & 15.2 & 14.1 & 10.5 & 13.2 & 1.4 & 1.3 & 1.0 & 1.3 \\
\hline Switzerland & 18.0 & 18.0 & 13.8 & 16.6 & 1.7 & 1.7 & 1.3 & 1.5 \\
\hline United Kingdom & 15.0 & 14.0 & 11.7 & 13.5 & 1.4 & 1.3 & 1.1 & 1.3 \\
\hline United States & 14.3 & 13.6 & 11.3 & 13.1 & 1.3 & 1.3 & 1.1 & 1.2 \\
\hline Average & 16.0 & 16.0 & 13.4 & 15.1 & 1.5 & 1.5 & 1.3 & 1.4 \\
\hline
\end{tabular}

rates display as zero because of rounding.) The average decade percentage rates of productivity growth for all countries combined are 5.0, 5.0, and 2.6, consecutively, in the three decades, and 4.2 for the 30 -year period. There is considerable variation, though, both across countries and over

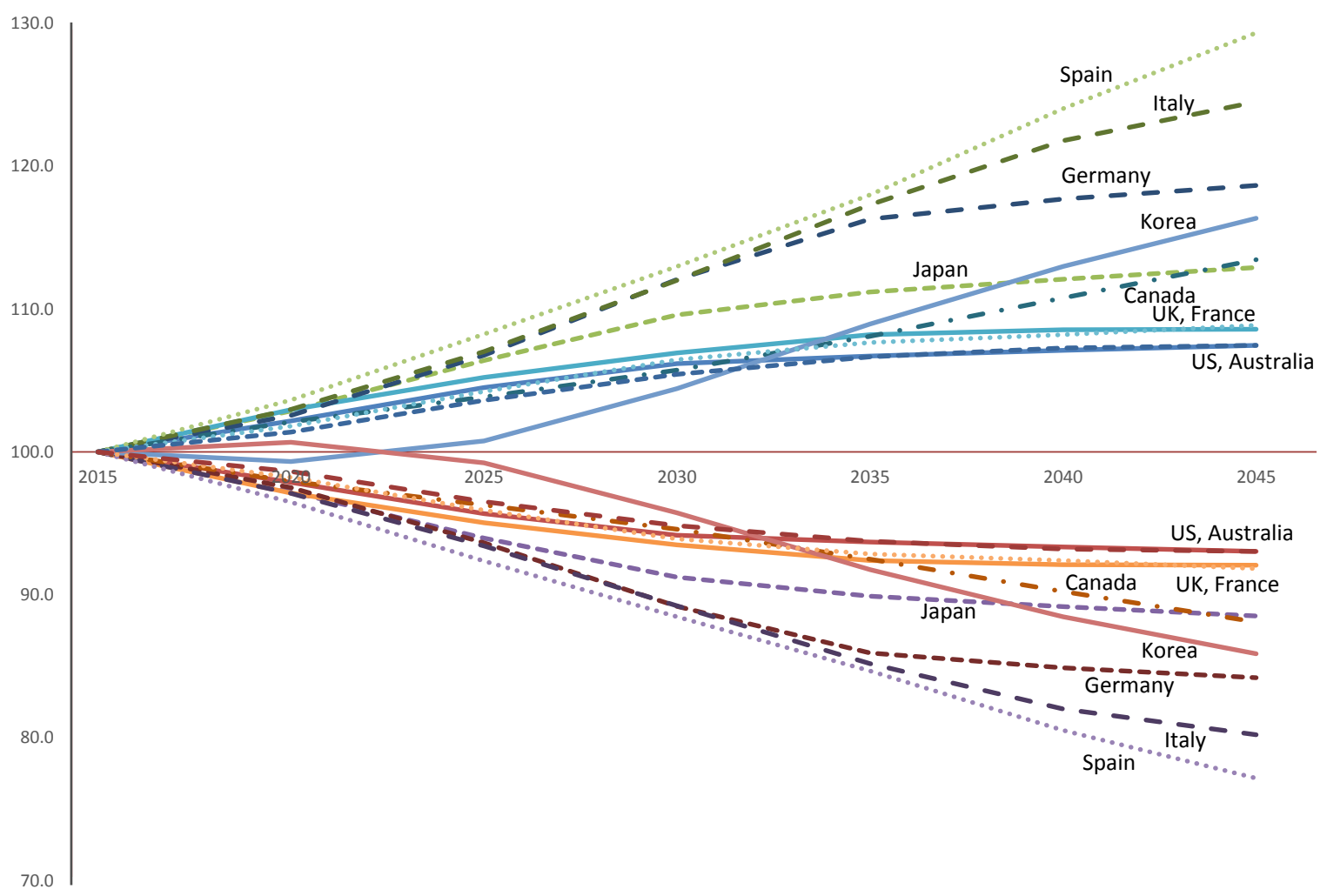

Figure 1. Indexes of GDP per capita when only the population changes (lower half); corresponding indexes of productivity required to prevent GDP per capita from declining (upper half). 
Table 5. Comparison of recent historical percentage rates of productivity growth with projected rates required to keep GDP per capita growing at $1 \%$ per year.

\begin{tabular}{|c|c|c|c|c|c|c|c|c|}
\hline & \multicolumn{4}{|c|}{ Growth rate per decade } & \multicolumn{4}{|c|}{ Growth rate per year } \\
\hline & \multicolumn{2}{|c|}{ Historical } & \multicolumn{2}{|c|}{ Projected } & \multicolumn{2}{|c|}{ Historical } & \multicolumn{2}{|c|}{ Projected } \\
\hline & $2005-15$ & $1985-2015$ & $2015-25$ & $2015-45$ & $2005-15$ & $1985-2015$ & $2015-25$ & $2015-45$ \\
\hline Australia & 13.3 & 16.1 & 15.3 & 13.1 & 1.3 & 1.5 & 1.4 & 1.2 \\
\hline Austria & 11.3 & - & 19.2 & 17.7 & 1.1 & - & 1.8 & 1.6 \\
\hline Belgium & 5.1 & 15.7 & 17.7 & 15.5 & 0.5 & 1.5 & 1.6 & 1.4 \\
\hline Canada & 8.3 & 11.3 & 17.3 & 14.9 & 0.8 & 1.1 & 1.6 & 1.4 \\
\hline Denmark & 8.2 & 16.4 & 12.7 & 13.3 & 0.8 & 1.5 & 1.2 & 1.3 \\
\hline Finland & 3.9 & 23.7 & 16.4 & 13.1 & 0.4 & 2.1 & 1.5 & 1.2 \\
\hline France & 7.3 & 17.0 & 16.0 & 13.4 & 0.7 & 1.6 & 1.5 & 1.3 \\
\hline Germany & 8.4 & 17.9 & 17.7 & 16.8 & 0.8 & 1.7 & 1.6 & 1.6 \\
\hline Ireland & 49.5 & 48.3 & 15.8 & 14.2 & 4.1 & 4.0 & 1.5 & 1.3 \\
\hline Italy & 0.4 & 9.5 & 18.0 & 18.6 & 0.0 & 0.9 & 1.7 & 1.7 \\
\hline Japan & 7.9 & 21.8 & 14.6 & 15.1 & 0.8 & 2.0 & 1.4 & 1.4 \\
\hline Korea & 38.7 & 65.3 & 11.3 & 16.0 & 3.3 & 5.2 & 1.1 & 1.5 \\
\hline Netherlands & 5.7 & 11.8 & 17.1 & 15.2 & 0.6 & 1.1 & 1.6 & 1.4 \\
\hline New Zealand & 10.6 & 13.7 & 13.2 & 12.3 & 1.0 & 1.3 & 1.2 & 1.2 \\
\hline Norway & -2.4 & 16.7 & 14.4 & 14.1 & -0.2 & 1.6 & 1.4 & 1.3 \\
\hline Spain & 13.2 & 10.4 & 19.3 & 20.1 & 1.2 & 1.0 & 1.8 & 1.8 \\
\hline Sweden & 7.9 & 18.4 & 15.2 & 13.2 & 0.8 & 1.7 & 1.4 & 1.3 \\
\hline Switzerland & 6.7 & 9.2 & 18.0 & 16.6 & 0.7 & 0.9 & 1.7 & 1.5 \\
\hline United Kingdom & 4.6 & 17.1 & 15.0 & 13.5 & 0.5 & 1.6 & 1.4 & 1.3 \\
\hline United States & 10.2 & 16.9 & 14.3 & 13.1 & 1.0 & 1.6 & 1.3 & 1.2 \\
\hline Average & 10.9 & 19.9 & 16.0 & 15.1 & 1.0 & 1.8 & 1.5 & 1.4 \\
\hline
\end{tabular}

Note: The historical series are based on GDP per hour worked (OECD 2017d); Austria 1985 values are not available.

the decades: the highest decade rate of productivity increase required to stop GDP per capita from declining is 9.3 per cent in Italy in 2025-35; the lowest rate is 0.1 per cent, in New Zealand and Sweden in 2035-45. For the period 2015-45 as a whole, the rates range from 1.7 per cent per decade (New Zealand) to 8.7 per cent (Spain).

If sights are set higher and the target rate of growth of GDP per capita is pegged at 1 per cent per year, or 10.5 per cent per decade, the required productivity growth rates are of course much greater. The 2015-45 growth rate is 15.1 per cent per decade on average across the twenty countries; the lowest is 12.3 per cent per decade (New Zealand), and the highest is 20.1 per cent (Spain).

An obvious question is how the projected requirements for productivity growth rates compare with actual historical rates. We provide in Table 5 a comparison of the rates required to achieve 1 per cent growth in GDP per capita over the full thirty-year projection period and over the first ten years of that period, 2015-45 and 2015-25, with rates in the most recent historical periods of corresponding length, 1985-2015 and 2005-15.

Historically, productivity growth rates in the decade 2005-15 were below the actual thirty-year averages in most countries, well below in many; only two countries had rates that were higherIreland and Spain. The all-countries average for 2005-15 was just a little over half the thirty-year average, indicating that productivity growth had slowed conspicuously by the early years of this century. The required growth rates projected for 2015-25 are higher than the 2005-15 actual rates, and generally much higher: the all-countries average of required rates for 2015-25 is 16.0 per cent per decade, while the 2005-15 average of actual rates is 10.9. In only Ireland and Korea is the reverse true; for those two, the projected rates are very much lower than the 2005-15 actual rates. Overall, achieving 1 per cent growth in GDP per capita would require a reversal of the historical decline in productivity growth in most industrialised countries. 
Table 6. Effects on projected indexes of GDP per capita of an increase in older-worker labour force participation rates $(\Delta \mathrm{r})$.

\begin{tabular}{|c|c|c|c|c|c|c|c|c|}
\hline & \multicolumn{4}{|c|}{ With population change only } & \multicolumn{4}{|c|}{ With population change plus $\Delta \mathrm{r}$} \\
\hline & 2015 & 2025 & 2035 & 2045 & 2015 & 2025 & 2035 & 2045 \\
\hline Australia & 100.0 & 95.8 & 93.9 & 93.3 & 100.0 & 97.6 & 95.7 & 95.1 \\
\hline Austria & 100.0 & 92.7 & 85.6 & 82.7 & 100.0 & 93.3 & 86.4 & 83.4 \\
\hline Belgium & 100.0 & 93.9 & 89.2 & 87.6 & 100.0 & 94.4 & 89.8 & 88.1 \\
\hline Canada & 100.0 & 94.2 & 90.2 & 88.9 & 100.0 & 96.3 & 92.4 & 90.9 \\
\hline Denmark & 100.0 & 98.0 & 93.7 & 92.6 & 100.0 & 99.2 & 95.0 & 93.8 \\
\hline Finland & 100.0 & 94.9 & 93.4 & 93.0 & 100.0 & 95.9 & 94.3 & 94.0 \\
\hline France & 100.0 & 95.2 & 92.6 & 92.3 & 100.0 & 95.7 & 93.2 & 92.8 \\
\hline Germany & 100.0 & 93.8 & 86.4 & 84.7 & 100.0 & 95.3 & 88.1 & 86.1 \\
\hline Ireland & 100.0 & 95.4 & 94.5 & 90.6 & 100.0 & 97.2 & 96.6 & 93.0 \\
\hline Italy & 100.0 & 93.6 & 85.6 & 80.8 & 100.0 & 94.8 & 87.0 & 82.2 \\
\hline Japan & 100.0 & 96.4 & 92.7 & 88.5 & 100.0 & 100.8 & 97.3 & 93.7 \\
\hline Korea & 100.0 & 99.3 & 92.0 & 86.3 & 100.0 & 103.9 & 98.1 & 92.7 \\
\hline Netherlands & 100.0 & 94.3 & 88.9 & 88.2 & 100.0 & 95.1 & 89.8 & 89.0 \\
\hline New Zealand & 100.0 & 97.6 & 95.2 & 95.1 & 100.0 & 100.4 & 98.2 & 97.8 \\
\hline Norway & 100.0 & 96.5 & 92.5 & 90.7 & 100.0 & 98.2 & 94.4 & 92.5 \\
\hline Spain & 100.0 & 92.6 & 85.1 & 77.9 & 100.0 & 93.1 & 85.8 & 78.5 \\
\hline Sweden & 100.0 & 95.9 & 92.9 & 92.8 & 100.0 & 97.2 & 94.2 & 94.1 \\
\hline Switzerland & 100.0 & 93.6 & 87.6 & 85.1 & 100.0 & 95.0 & 89.3 & 86.6 \\
\hline United Kingdom & 100.0 & 96.1 & 93.1 & 92.1 & 100.0 & 97.4 & 94.6 & 93.5 \\
\hline United States & 100.0 & 96.6 & 93.9 & 93.3 & 100.0 & 99.6 & 96.9 & 96.1 \\
\hline Average & 100.0 & 95.3 & 91.0 & 88.8 & 100.0 & 97.0 & 92.8 & 90.7 \\
\hline
\end{tabular}

Note: $\Delta \mathrm{r}$ stands for an increase by half of all labour force participation rates for the population aged 65 and over between 2015 and 2025; the new rates are held constant thereafter.

Table 7. Effects on projected indexes of GDP per capita of a decrease in unemployment rates $(\Delta u)$.

\begin{tabular}{|c|c|c|c|c|c|c|c|c|}
\hline & \multicolumn{4}{|c|}{ With population change only } & \multicolumn{4}{|c|}{ With population change plus $\Delta \mathrm{u}$} \\
\hline & 2015 & 2025 & 2035 & 2045 & 2015 & 2025 & 2035 & 2045 \\
\hline Australia & 100.0 & 95.8 & 93.9 & 93.3 & 100.0 & 97.7 & 95.8 & 95.1 \\
\hline Austria & 100.0 & 92.7 & 85.6 & 82.7 & 100.0 & 94.5 & 87.3 & 84.3 \\
\hline Belgium & 100.0 & 93.9 & 89.2 & 87.6 & 100.0 & 96.8 & 92.0 & 90.3 \\
\hline Canada & 100.0 & 94.2 & 90.2 & 88.9 & 100.0 & 96.4 & 92.4 & 91.0 \\
\hline Denmark & 100.0 & 98.0 & 93.7 & 92.6 & 100.0 & 100.0 & 95.6 & 94.5 \\
\hline Finland & 100.0 & 94.9 & 93.4 & 93.0 & 100.0 & 98.0 & 96.4 & 96.1 \\
\hline France & 100.0 & 95.2 & 92.6 & 92.3 & 100.0 & 98.9 & 96.3 & 95.9 \\
\hline Germany & 100.0 & 93.8 & 86.4 & 84.7 & 100.0 & 95.4 & 87.7 & 86.1 \\
\hline Ireland & 100.0 & 95.4 & 94.5 & 90.6 & 100.0 & 98.9 & 98.0 & 93.8 \\
\hline Italy & 100.0 & 93.6 & 85.6 & 80.8 & 100.0 & 97.7 & 89.5 & 84.5 \\
\hline Japan & 100.0 & 96.4 & 92.7 & 88.5 & 100.0 & 97.5 & 93.8 & 89.5 \\
\hline Korea & 100.0 & 99.3 & 92.0 & 86.3 & 100.0 & 100.4 & 93.0 & 87.3 \\
\hline Netherlands & 100.0 & 94.3 & 88.9 & 88.2 & 100.0 & 96.5 & 90.9 & 90.2 \\
\hline New Zealand & 100.0 & 97.6 & 95.2 & 95.1 & 100.0 & 98.4 & 96.0 & 95.9 \\
\hline Norway & 100.0 & 96.5 & 92.5 & 90.7 & 100.0 & 97.1 & 93.1 & 91.2 \\
\hline Spain & 100.0 & 92.6 & 85.1 & 77.9 & 100.0 & 96.5 & 88.7 & 81.1 \\
\hline Sweden & 100.0 & 95.9 & 92.9 & 92.8 & 100.0 & 97.0 & 93.9 & 93.9 \\
\hline Switzerland & 100.0 & 93.6 & 87.6 & 85.1 & 100.0 & 94.3 & 88.3 & 85.7 \\
\hline United Kingdom & 100.0 & 96.1 & 93.1 & 92.1 & 100.0 & 96.8 & 93.8 & 92.8 \\
\hline United States & 100.0 & 96.6 & 93.9 & 93.3 & 100.0 & 97.4 & 94.7 & 94.0 \\
\hline Average & 100.0 & 95.3 & 91.0 & 88.8 & 100.0 & 97.3 & 92.9 & 90.7 \\
\hline
\end{tabular}

Note: $\Delta \mathrm{u}$ stands for a reduction of all unemployment rates by one-third between 2015 and 2025 ; the new rates are held constant thereafter. 
Table 8. Effects on projected indexes of GDP per capita of an increase in average hours worked per year $(\Delta \mathrm{h})$.

\begin{tabular}{|c|c|c|c|c|c|c|c|c|}
\hline & \multicolumn{4}{|c|}{ With population change only } & \multicolumn{4}{|c|}{ With population change plus $\Delta \mathrm{h}$} \\
\hline & 2015 & 2025 & 2035 & 2045 & 2015 & 2025 & 2035 & 2045 \\
\hline Australia & 100.0 & 95.8 & 93.9 & 93.3 & 100.0 & 100.6 & 98.6 & 97.9 \\
\hline Austria & 100.0 & 92.7 & 85.6 & 82.7 & 100.0 & 97.3 & 89.8 & 86.8 \\
\hline Belgium & 100.0 & 93.9 & 89.2 & 87.6 & 100.0 & 98.6 & 93.7 & 91.9 \\
\hline Canada & 100.0 & 94.2 & 90.2 & 88.9 & 100.0 & 98.9 & 94.7 & 93.3 \\
\hline Denmark & 100.0 & 98.0 & 93.7 & 92.6 & 100.0 & 102.9 & 98.4 & 97.2 \\
\hline Finland & 100.0 & 94.9 & 93.4 & 93.0 & 100.0 & 99.6 & 98.0 & 97.7 \\
\hline France & 100.0 & 95.2 & 92.6 & 92.3 & 100.0 & 100.0 & 97.3 & 96.9 \\
\hline Germany & 100.0 & 93.8 & 86.4 & 84.7 & 100.0 & 98.5 & 90.7 & 88.9 \\
\hline Ireland & 100.0 & 95.4 & 94.5 & 90.6 & 100.0 & 100.2 & 99.2 & 95.1 \\
\hline Italy & 100.0 & 93.6 & 85.6 & 80.8 & 100.0 & 98.3 & 89.9 & 84.8 \\
\hline Japan & 100.0 & 96.4 & 92.7 & 88.5 & 100.0 & 101.2 & 97.4 & 92.9 \\
\hline Korea & 100.0 & 99.3 & 92.0 & 86.3 & 100.0 & 104.2 & 96.6 & 90.6 \\
\hline Netherlands & 100.0 & 94.3 & 88.9 & 88.2 & 100.0 & 99.1 & 93.3 & 92.6 \\
\hline New Zealand & 100.0 & 97.6 & 95.2 & 95.1 & 100.0 & 102.5 & 99.9 & 99.8 \\
\hline Norway & 100.0 & 96.5 & 92.5 & 90.7 & 100.0 & 101.3 & 97.2 & 95.2 \\
\hline Spain & 100.0 & 92.6 & 85.1 & 77.9 & 100.0 & 97.2 & 89.4 & 81.8 \\
\hline Sweden & 100.0 & 95.9 & 92.9 & 92.8 & 100.0 & 100.7 & 97.5 & 97.5 \\
\hline Switzerland & 100.0 & 93.6 & 87.6 & 85.1 & 100.0 & 98.3 & 92.0 & 89.3 \\
\hline United Kingdom & 100.0 & 96.1 & 93.1 & 92.1 & 100.0 & 100.9 & 97.7 & 96.7 \\
\hline United States & 100.0 & 96.6 & 93.9 & 93.3 & 100.0 & 101.5 & 98.6 & 97.9 \\
\hline Average & 100.0 & 95.3 & 91.0 & 88.8 & 100.0 & 100.1 & 95.5 & 93.3 \\
\hline
\end{tabular}

Note: $\Delta \mathrm{h}$ stands for a general increase of 5 per cent in average hours worked between 2015 and 2025; the new levels are held constant thereafter.

A slightly more optimistic view is, perhaps, supported by comparing the projected required rates with historical thirty-year rates rather than with those for only the most recent decade. The all-countries average rate of productivity growth per decade in 1985-2015 was 19.9 per cent; the all-countries average projected rates are lower than that -16.0 for $2015-25$ and 15.1 for $2015-45$. Among individual countries, thirteen have projected rates for 2015-25 that are lower than the historical thirty-year rates, and fourteen have projected rates for 2015-45 that are lower than those rates. (All of these calculations exclude Austria, for which a 1985-2015 productivity growth rate was not available.) How one views the possibilities for annual rates of 1 per cent productivity growth in the future may thus depend to some extent on one's choice of historical benchmarks, and on what one thinks is the likelihood of a reversal of the observed general downward trend.

\section{Could other changes provide significant offsets to population aging?}

Now let us consider alternatives to productivity growth as offset possibilities-in particular, changes in labour force participation rates $(r)$, unemployment rates $(u=1-e)$, and average hours worked $(h)$. Taking $r$ as an example, as in equation (5), $\bar{g}_{t}$ now represents the combined effect of altered participation rates and population change. To get some idea of how higher participation rates, representing deferred retirement, might offset population aging, we increase $r$ by half for all age groups over 65 by the year 2025, leaving the rates constant thereafter. The results are shown in Table 6. Alternatively, we replace $r$ with $e$ in equation (5); we lower all unemployment rates by one-third by 2025 (again, constant thereafter), and then reset $e=1-u$ accordingly; the results of this are shown in Table 7. Next, we replace $r$ with $h$ and reset the latter for all age groups at 5 per cent above the initial levels by 2025 ; the results are in Table 8 . Finally, we make a combined sub- 
Table 9. Combined effects on projected indexes of GDP per capita of increased labour force participation rates $(\Delta \mathrm{r})$, decreased unemployment rates $(\Delta \mathrm{u})$, and increased average hours worked per year $(\Delta \mathrm{h})$.

\begin{tabular}{|c|c|c|c|c|c|c|c|c|}
\hline & \multicolumn{4}{|c|}{ With population change only } & \multicolumn{4}{|c|}{ With population change plus $\Delta \mathrm{r}, \Delta \mathrm{u}, \Delta \mathrm{h}$} \\
\hline & 2015 & 2025 & 2035 & 2045 & 2015 & 2025 & 2035 & 2045 \\
\hline Australia & 100.0 & 95.8 & 93.9 & 93.3 & 100.0 & 104.5 & 102.5 & 101.8 \\
\hline Austria & 100.0 & 92.7 & 85.6 & 82.7 & 100.0 & 99.9 & 92.5 & 89.3 \\
\hline Belgium & 100.0 & 93.9 & 89.2 & 87.6 & 100.0 & 102.1 & 97.2 & 95.4 \\
\hline Canada & 100.0 & 94.2 & 90.2 & 88.9 & 100.0 & 103.5 & 99.3 & 97.7 \\
\hline Denmark & 100.0 & 98.0 & 93.7 & 92.6 & 100.0 & 106.3 & 101.8 & 100.5 \\
\hline Finland & 100.0 & 94.9 & 93.4 & 93.0 & 100.0 & 104.0 & 102.3 & 101.9 \\
\hline France & 100.0 & 95.2 & 92.6 & 92.3 & 100.0 & 104.4 & 101.6 & 101.2 \\
\hline Germany & 100.0 & 93.8 & 86.4 & 84.7 & 100.0 & 101.6 & 93.9 & 91.8 \\
\hline Ireland & 100.0 & 95.4 & 94.5 & 90.6 & 100.0 & 105.8 & 105.1 & 101.1 \\
\hline Italy & 100.0 & 93.6 & 85.6 & 80.8 & 100.0 & 103.8 & 95.4 & 90.1 \\
\hline Japan & 100.0 & 96.4 & 92.7 & 88.5 & 100.0 & 107.0 & 103.4 & 99.5 \\
\hline Korea & 100.0 & 99.3 & 92.0 & 86.3 & 100.0 & 110.3 & 104.1 & 98.4 \\
\hline Netherlands & 100.0 & 94.3 & 88.9 & 88.2 & 100.0 & 102.2 & 96.4 & 95.6 \\
\hline New Zealand & 100.0 & 97.6 & 95.2 & 95.1 & 100.0 & 106.3 & 103.9 & 103.5 \\
\hline Norway & 100.0 & 96.5 & 92.5 & 90.7 & 100.0 & 103.7 & 99.6 & 97.6 \\
\hline Spain & 100.0 & 92.6 & 85.1 & 77.9 & 100.0 & 101.8 & 93.8 & 85.9 \\
\hline Sweden & 100.0 & 95.9 & 92.9 & 92.8 & 100.0 & 103.1 & 100.1 & 99.9 \\
\hline Switzerland & 100.0 & 93.6 & 87.6 & 85.1 & 100.0 & 100.4 & 94.4 & 91.6 \\
\hline United Kingdom & 100.0 & 96.1 & 93.1 & 92.1 & 100.0 & 103.0 & 100.1 & 98.9 \\
\hline United States & 100.0 & 96.6 & 93.9 & 93.3 & 100.0 & 105.4 & 102.6 & 101.6 \\
\hline Average & 100.0 & 95.3 & 91.0 & 88.8 & 100.0 & 104.0 & 99.5 & 97.2 \\
\hline
\end{tabular}

Note: See Tables 6,7 , and 8 for definitions of $\Delta \mathrm{r}, \Delta \mathrm{u}$, and $\Delta \mathrm{h}$, respectively.

stitution to incorporate all three changes simultaneously in equation (5); the results are in Table 9. The changes we have chosen to make are arbitrary but substantial, and might be thought of as approximating realistic upper bounds. We could have introduced further changes in the second and third decades of the projection period, but a feature of these kinds of change is that they are effectively bounded, realistically if not absolutely. There are practical limits to how much one could expect hours of work or participation rates of older people to increase, or rates of unemployment to decrease. They are unlike productivity in that regard, which as far as we can tell at the moment can increase indefinitely, whether slowly or rapidly. (Longer-term effects on productivity of environmental degradation or natural resource depletion are another matter.)

Increasing participation rates by half for older age groups has some effects, mostly in the first decade, that are generally modest. With only population change, the average index of GDP per capita is 95.3 in 2025 and 88.8 by 2045; incorporating the participation changes as well raises the average index level to 97.0 in 2025 and to 90.7 in 2045. Decreasing all unemployment rates by a third has similarly rather small effects: average index levels are 97.3 in 2025, 90.7 in 2045. Increasing hours of work by 5 per cent has notably greater effects, yielding average index levels of 100.1 and 93.3; the decline in GDP per capita is completely offset in eleven of the twenty countries in 2025 by increasing average hours. There are no cases of complete offset in 2035 or 2045; GDP per capita is still below its initial level in all countries in those years. Nevertheless, the effects are substantial. To put the magnitude of the change in average hours in perspective, 40 hours per week would become 42 with a 5 per cent increase; an 8-hour day would be increased by 24 minutes. (That is not a comment on the feasibility or desirability of such an increase, just a matter of arithmetic perspective.)

The final experiment with these changes involves hypothetically implementing them all at once, as in Table 9. The results of doing that is to virtually eliminate the effects of population 
Table 10. Effects on projected indexes of GDP per capita of alternative assumptions about agerelated productivity $(\Delta \mathrm{q})$.

\begin{tabular}{|c|c|c|c|c|c|c|c|c|}
\hline & \multicolumn{4}{|c|}{ Without $\Delta \mathrm{q}$} & \multicolumn{4}{|c|}{ With $\Delta \mathrm{q}$} \\
\hline & 2015 & 2025 & 2035 & 2045 & 2015 & 2025 & 2035 & 2045 \\
\hline Australia & 100.0 & 95.8 & 93.9 & 93.3 & 100.0 & 96.1 & 93.7 & 93.2 \\
\hline Austria & 100.0 & 92.7 & 85.6 & 82.7 & 100.0 & 93.2 & 85.7 & 82.4 \\
\hline Belgium & 100.0 & 93.9 & 89.2 & 87.6 & 100.0 & 93.9 & 88.8 & 87.2 \\
\hline Canada & 100.0 & 94.2 & 90.2 & 88.9 & 100.0 & 94.2 & 90.0 & 88.7 \\
\hline Denmark & 100.0 & 98.0 & 93.7 & 92.6 & 100.0 & 98.0 & 93.9 & 92.7 \\
\hline Finland & 100.0 & 94.9 & 93.4 & 93.0 & 100.0 & 95.1 & 93.4 & 93.1 \\
\hline France & 100.0 & 95.2 & 92.6 & 92.3 & 100.0 & 94.8 & 92.1 & 92.0 \\
\hline Germany & 100.0 & 93.8 & 86.4 & 84.7 & 100.0 & 93.8 & 86.1 & 84.2 \\
\hline Ireland & 100.0 & 95.4 & 94.5 & 90.6 & 100.0 & 94.7 & 93.0 & 89.5 \\
\hline Italy & 100.0 & 93.6 & 85.6 & 80.8 & 100.0 & 93.2 & 84.8 & 80.1 \\
\hline Japan & 100.0 & 96.4 & 92.7 & 88.5 & 100.0 & 96.5 & 92.3 & 87.6 \\
\hline Korea & 100.0 & 99.3 & 92.0 & 86.3 & 100.0 & 98.8 & 90.8 & 84.5 \\
\hline Netherlands & 100.0 & 94.3 & 88.9 & 88.2 & 100.0 & 94.0 & 88.7 & 88.0 \\
\hline New Zealand & 100.0 & 97.6 & 95.2 & 95.1 & 100.0 & 97.3 & 94.9 & 95.3 \\
\hline Norway & 100.0 & 96.5 & 92.5 & 90.7 & 100.0 & 96.8 & 92.4 & 90.5 \\
\hline Spain & 100.0 & 92.6 & 85.1 & 77.9 & 100.0 & 92.2 & 84.1 & 77.1 \\
\hline Sweden & 100.0 & 95.9 & 92.9 & 92.8 & 100.0 & 96.5 & 92.8 & 92.8 \\
\hline Switzerland & 100.0 & 93.6 & 87.6 & 85.1 & 100.0 & 93.7 & 87.2 & 84.3 \\
\hline United Kingdom & 100.0 & 96.1 & 93.1 & 92.1 & 100.0 & 96.3 & 92.8 & 91.9 \\
\hline United States & 100.0 & 96.6 & 93.9 & 93.3 & 100.0 & 96.5 & 93.9 & 93.2 \\
\hline Average & 100.0 & 95.3 & 91.0 & 88.8 & 100.0 & 95.3 & 90.6 & 88.4 \\
\hline
\end{tabular}

Note: $\Delta \mathrm{q}$ stands for replacement of flat age/productivity profile with profile that has lower productivity at young ages and old ages. See text for details.

aging in 2025 and, if not eliminate them in 2035 and 2045, at least reduce them drastically. The increase in average hours of work is the dominant contributor to these collective effects.

There is an important consideration to keep mind in judging the foregoing results. The calculations underlying tables 6-9 are based on equation (5), which assumes that the index of productivity remains at its base period level; other variables change but the productivity index remains at $\bar{p}_{0}=1$. The implication is that all of the determinants of productivity are unaffected when participation rates, unemployment rates, or average hours of work are changed. That is to say, the amount of capital per unit of labour remains the same, as do the scale of production, the distribution of industrial output between high and low productivity industries, and so on (see above). That is a strong assumption. It would have to be accepted especially in order to view the average-hours effects as potentially realistic.

\section{How much does the age composition of the labour force matter?}

We noted earlier that differences in productivity among age groups are not directly observable at the aggregate level. However there is a substantial literature on inferential estimation of age/ productivity profiles based on age/wage profiles. An inverse "u-shape" seems well established; Mincer (1974) expressed the natural logarithm of earnings as a linear function of years of education and a quadratic function of potential work experience; and, as Murphy and Welch observed, "the quadratic in experience... has been universally accepted" (1990: 203). However, whether wages are a good indicator of productivity remains a question. There is a common perception that older workers are overpaid and younger ones underpaid. That idea has been tested using data at the workplace level to estimate production functions, from which measures of worker productiv- 
ity are derived and compared with observed wages to determine whether workers are paid their marginal products. Hellerstein and Neumark (2004) estimate that in the United States workers over 55 are roughly 20 per cent overpaid and younger workers about 10 per cent underpaid. Crépon et al. (2003) find much the same differences in France. However, using similar procedures, many authors find no evidence that the wage profile differs from the productivity profile; among them are Dostie (2011) for Canada, van Ours and Stoeldraijer (2011) for the Netherlands, and Mahlberg et al. (2013) for Austria.

What we have done here is arbitrarily chosen a profile that is roughly consistent with suggestions in the literature, implement it for all countries by resetting the $q$ values (previously set to 1) in equation (3), and then recalculate the $\bar{d}$ values shown previously in Table 2 . We can thus get some idea as to how much the projections of population aging on GDP per capita might be affected if we were able to incorporate actual profiles in the calculations. The $q$ values are fixed over time in equation (3); changing them thus amounts only to changing the $a_{x 0}$ weights in the equation; the weights remain the same for both the base and projection years.

The new age/productivity profile reflects the assumption of lower productivity at younger ages and again at older ages. Specifically, the $q$ values are as follows: $q=1.0$ for age groups 30-34 to $55-59 ; q=0.5$ for the age group 15-19, with linear interpolation for the groups between 15-19 and 30-34; and $q=0.7$ for age groups 70-74 and older, with linear interpolation between 55-59 and $70-74$.

Table 10 compares the $\bar{d}$ indexes calculated using the new age/productivity profile with those from Table 2, which assumed a flat profile. The differences are generally very small. The average difference to one decimal place is 0.0 in 2025 and -0.4 in each of 2035 and 2045; allowing for lower productivity at younger and older ages changes the impact of population aging on GDP per capita only slightly. Another age/productivity profile would produce different effects, but our calculations suggest that whatever (plausible) profile one might choose, the effects would be very small. That seems consistent with the observation by Disney that "the case for "productivity pessimism' with an older workforce is unfounded" (1996: 188), but not with the tentative conclusion of Laitner and Stolyarov that the "aging of the US work force seems more likely to increase aggregate productivity" (2005: 17). The biggest effects by far come from the increased proportion of dependents in the population, most particularly older dependents.

\section{In summary}

Population aging and a rising dependency ratio are widespread demographic characteristics among industrialized nations, now and prospectively for decades to come. We have used a particular set of population projections provided by the United Nations to document this phenomenon for twenty member countries of the OECD. Population projections for an individual country can differ depending on the assumptions about future fertility, mortality, and immigration rates, and they can be revised as the passage of time provides new information. But collectively the outlook across twenty countries seems well established: population aging will be with us for a long time, and so too its economic implications. Prominent among those implications is continuing downward pressure on the ability of an economy to generate output per capita.

We have provided an index-based framework for calculating the prospective effects of population aging on per capita GDP and used it to show what can happen over three decades, starting from 2015. According to our calculations, GDP per capita declines in each country, in each decade. The rates of decline vary across countries, but there is no exception to the declining trend: the 
future is one in which smaller proportions of the population in their productive years and larger proportions in their dependent years will put downward pressure on income per capita.

A natural question to ask is whether there could be some other type of change on the supply side of an economy to counter the effects of population aging-most especially, could an increase in productivity do the job? To that end, we calculated the productivity growth rate that would be required for each country in each decade to exactly offset those effects, thus keeping GDP per capita at its 2015 level. We then did the calculation again but assuming GDP per capita to increase by 1 per cent per annum rather than zero—a sufficient growth in productivity, that is, to eliminate the effects of aging plus whatever additional increase would be required to have GDP per capita rise by 1 per cent per year. Taking the twenty countries as a whole, the average productivity growth rate (a simple unweighted arithmetic average) required to just offset the aging effects over the full 30 years from 2015 to 2045 would be 4.2 per cent per decade, or approximately 0.4 per cent per year. On the other hand, to achieve an overall increase of 1 per cent in GDP per capita would require an average productivity growth of 15.1 per cent per decade, or 1.4 per cent per year. Could we expect enough growth in productivity to have incomes growing at 1 per cent per year? The rates that would be required for the current decade are generally higher than those observed for the one past. However, if the comparison is with the next three decades, the projected required rates for many countries are lower, or at least close to the thirty-year historical rates. One's view of the attainability of the projected rates may thus depend on whether one compares them with more recent or longer-term historical rates.

The next question that we addressed was whether there could be offsets to population aging other than productivity growth. We considered, within our framework, possible increases in labour participation rates (representing deferred retirement), reduced unemployment rates, and increases in average hours worked. An increase of 5 per cent in average hours did in fact provide substantial offsets to the aging-induced declines in GDP per capita, in many cases actually eliminating the declines in the first decade of the 30-year projection period; other offsets considered had only minor effects. As we noted, an increase of 5 per cent in average hours would increase a 40-hour work week to 42 and add 24 minutes to an 8-hour day. The apparent effects of increasing average hours worked on GDP per capita are certainly substantial, although whether or not they would be societally acceptable is open to question. Also, as we pointed out, the assumption in the calculations is that productivity remains the same when the change in hours is introduced - that is, amount of capital per unit of labour and other determinants of productivity are unaltered. The assumption is thus an important one in judging the apparent effectiveness of increasing average hours.

The final experimental calculation that we did assumed a change in the age/productivity profile of the employed labour force. In the previous calculations, age differences were ignored; the profile was assumed to be flat (in the absence of data based on actual measurement). The modified profile assumed lower productivity per worker at the young end of the working-age spectrum and again at the old end, based on suggestions in the relevant literature. Changing the profile this way altered only slightly our earlier calculations. Thus, the age distribution of employees seems to matter relatively little in the overall framework of population aging and GDP per capita.

\section{Acknowledgement}

As concerns compliance with ethical standards, this study was completed without funding. The authors declare that they have no conflict of interest. 


\section{References}

Acemoglu, D., and P. Restrepo. 2017. Secular Stagnation: The Effect of Aging on Economic Growth in the Age of Automation. Working Paper 23077. Cambridge, MA: National Bureau for Economic Research. http://www.nber.org/papers/w23077

Bloom, D.E., D. Canning, and G. Fink. 2011. Implications of Population Aging for Economic Growth. Working Paper 16705. Cambridge, MA: National Bureau for Economic Research. http://www. nber.org/papers/w16705

Crépon B., N. Deniau, and S. Perez-Duarte. 2003. Productivité et salaire des travailleurs âgés. Revue française d'économie 18(1):157-85.

Denton, F.T., and B.G. Spencer. 1973. A simulation analysis of the effects of population change on a neoclassical economy. Journal of Political Economy 81(2):356-75.

- 2000. Population aging and its economic costs: A survey of the issues and evidence. Canadian Journal on Aging 19(1):1-31.

Disney, R. 1996. Can We Afford to Grow Older? A Perspective on the Economics of Aging, Cambridge, MA, and London (UK): The MIT Press.

Dostie, B. 2011. Wages, productivity, and aging. De Economist Netherlands Economic Review 159(2):139_ 58. DOI 10.1007/s10645-011-9166-5.

Feyrer, J. 2007. Demographics and productivity. Review of Economics and Statistics 89(1):100-09.

Gordon, R.J. 2014. The turtle's progress: Secular stagnation meets the headwinds, in Secular Stagnation: Facts, Causes, and Cures, edited by C. Teulings and R. Baldwin. London: Centre for Economic Policy Research, p. 47-61.

- 2016. The Rise and Fall of American Growth: The US Standard of Living Since the Civil War. Princeton, NJ: Princeton University Press.

Hansen, A. 1939. Economic progress and the declining population growth. American Economic Review 29(1):1-15.

Hellerstein, J., and D. Neumark. 2004. Production Function and Wage Equation Estimation with Heterogeneous Labor: Evidence from a New Matched Employer-Employee Data Set. Working Paper 10325. Cambridge, MA: National Bureau for Economic Research. http://www.nber.org/papers/w10325

IUSSP (International Union for the Scientific Study of Population). 1979. Economic and Demographic Change: Issues for the 1980s; Proceedings of the Conference, Helsinki, 1978. 3 vols. Liege (Belgium): IUSSP.

Keynes, J.M. 1937. Some economic consequences of a declining population. Eugenics Review 29:13-17.

Laitner, J., and D. Stolyarov. 2005. Technological Progress and Worker Productivity at Different Ages. Working Paper WP 2005-107. Ann Arbor, MI: Retirement Research Centre. DOI org/10.2139/ ssrn.1093842

Lee, R.D., B. Arthur, and G. Rodgers. 1988. Economics of Changing Age Distribution in Developed Countries. Amsterdam: Oxford University Press.

Maestas, N., K.J. Mullen, and D. Powell. 2016. The Effect of Population Aging on Economic Growth, the Labor Force and Productivity. Working Paper No. 22452. Cambridge, MA: National Bureau for Economic Research. http://www.nber.org/papers/w10325 
Mahlberg, B., I. Freund, J. Crespo Cuaresma, and A. Prskawetz. 2013. Ageing, productivity, and wages in Austria. Labour Economics 22:5-15.

Mincer, J. 1974. Schooling, Experience, and Earnings. New York: National Bureau of Economic Research, Columbia University Press.

Murphy, K.M., and F. Welch. 1990. Empirical age-earnings profiles. Journal of Labor Economics 8(2):202-29.

National Research Council. 2012. Aging and the Macroeconomy: Long-Term Implications of an Older Population. Washington: The National Academies Press.

OECD (Organization for Economic Co-operation and Development). 2017a. Average annual hours actually worked per worker. Labour-Labour Force Statistics-Hours worked. http://stats.oecd. org/; accessed 02 February 2017.

. 2017b. Average usual weekly hours worked on the main job. Labour-Labour Force Statistics-Hours worked. http://stats.oecd.org/; accessed 02 February 2017.

. 2017c. Level of GDP per capita and productivity: GDP per hour worked (drop-down Subject item). Productivity—Productivity and ULC - Annual, Total Economy—Level of GDP per capita and productivity. http://stats.oecd.org/, accessed 04 June 2018.

—. 2017d. Usual hours worked by weekly hour bands. Labour-Labour Force StatisticsHours worked. http://stats.oecd.org/; accessed 02 February 2017.

Statistics Canada. 2017. Labour Force Survey estimates (LFS), by usual hours worked, main or all jobs, sex and age group, unadjusted for seasonality, monthly (persons unless otherwise noted). CANSIM Table 282-0015. http://www5.statcan.gc.ca/cansim/a26?lang=eng\&id=2820015\&p2=33; accessed 02 February 2017.

Steinmann, G. (ed.). 1984. Economic Consequences of Population Change in Industrialized Countries: Proceedings of the Conference on Population Economics Held at the University of Paderborn, West Germany, June 1-3, 1983. Studies in Contemporary Economics 8. Berlin-Heidelberg: Springer-Verlag.

Summers, L.H. 2014. Reflections on the "New Secular Stagnation Hypothesis," in Secular Stagnation: Facts, Causes, and Cures, edited by C. Teulings and R. Baldwin. London: Centre for Economic Policy Research, p. 27-40.

- 2016. The age of secular stagnation: What it is and what to do about it. Foreign Affairs (March/April). https://www.foreignaffairs.com/articles/united-states/2016-02-15/age-secularstagnation

Teulings, C., and R. Baldwin (eds.). 2014. Secular Stagnation: Facts, Causes, and Cures. London: Centre for Economic Policy Research.

United Nations. 2015. World Population Prospects: The 2015 Revision; Methodology of the United Nations Population Estimates and Projections. Working Paper No. ESA/P/WP.242. New York: United Nations Population Division, Department of Economic and Social Affairs.

- 2017. World Population Prospects—Standard Projections_-Population indicators. https:// esa.un.org/unpd/wpp/Download/Standard/Population/; accessed 02 February 2017.

van Ours, J.C., and L. Stoeldraijer. 2011. Age, wage, and productivity in Dutch manufacturing. De Economist Netherlands Economic Review 159(2):113-37. DOI 10.1007/s10645-011-9159-4.

World Bank. 2017. Armed forces personnel (\% of total labor force). https://data.worldbank.org/ indicator/ms.mil.totl.tf.zs; accessed 21 March 2017. 


\section{APPENDIX: Data and associated calculations}

The United Nations population projections are mid-year projections (interpreted for our purposes as close approximations to annual averages). They are provided at five-year intervals, starting in 2015 and extending to 2100, separately for males and females, for five-year age groups from 0-4 to 95-99, and with an open-ended 100-and-over group at the end. The UN source also provides population numbers for the base year 2015. The base year values for $r, e$, and $h$ that we require for our calculations were carried out using OECD annual average series for $L, E$, and $H$, which in turn were derived from survey data provided by the individual countries (the $q$ values are set by us by assumption). The $L$ and $E$ series were available for all countries for five-year age groups, by sex, from 15-19 to 65-69; they were available for most countries up to 70-74, and for some $E$ (but not $L$ ) was available up to 80-84. (Unemployment is assumed by us to be zero for older age groups when only $E$ is available; thus, $L=E$ in those cases.) Where the data did not allow the calculation of participation rates beyond 70-74 (or 65-69 in some cases, 80-84 in others) we assumed that the rate declined by half for each subsequent age group. Hours series in the form of usual hours worked on main job were available for the same age-sex groups as $E$ from OECD (2017b). Also available for each country from OECD (2017a) were average hours actually worked, but only in the aggregate, not for age-sex groups. What we did then was apply an adjustment factor to the usual hours series by multiplying average usual hours in each age-sex group by the overall ratio of actual to usual hours. ${ }^{7}$

Special treatment was required for three countries: Japan, Switzerland, and Canada. For Japan, the usual hours series was available only for specified bands: 1-19 hours, 20-29, 30-34, 35-39, and 40+ (OECD 2017d). We took the mid-point in each band up to 35-39 hours, and assumed 43 hours for the $40+$ category. For Switzerland, usual hours of work were not reported for the age group 65 and over; here, we assumed that the ratio of usual hours for ages 65 and over to usual hours for ages 60-64 was the same as the average ratio for the other countries for which it could be calculated. For Canada, no usual hours series was available from the OECD source. We therefore made an exception to our "use only OECD labour data" rule, and used "actual average hours worked" from Statistics Canada (2017).

As noted in the main body of the text, survey coverage and definitions can vary to some extent from country to country within the OECD reporting framework. Where there are exclusions from the labour force, one would assume the armed forces would be one of the larger groups in most if not all countries. (Some countries explicitly report only the civilian labour force to the OECD.) To see how much difference this exclusion might make, we checked the proportions of armed forces in the total labour force in 2014, as reported by the World Bank (2017). The average proportion over all twenty countries was 0.7 per cent; the lowest proportion was 0.3 per cent (New Zealand), and the highest was 2.4 per cent (Korea). All but three countries had proportions below 1.0 per cent, and ten had proportions of 0.5 per cent or less. We judge that the exclusion of armed forces from the labour force in some countries but not others would have had only small effects on our calculations. Whatever the details of the labour force definition in a particular country, the base period values and the projections for that country are mutually consistent.

7. The main-job usual hours series do not allow for absences from work because of illness, holidays, or vacation time, according to the OECD definitions, and thus generally overstate hours actually worked; they also do not allow for hours worked at secondary jobs. We suspect that the interpretation of usual hours may vary from country to country, but since the adjustment factors are country-specific, that should be caught up in the adjustment process, at least roughly. The adjustment factor ranges from 0.74 for Germany to 0.98 for Ireland. 